\title{
Analytika učení: nový přístup ke zkoumání učení (nejen) ve virtuálním prostř̌edí ${ }^{1}$
}

\author{
Libor Juhaňák, Jiří Zounek \\ Masarykova univerzita, Filozofická fakulta, Ústav pedagogických věd \\ Redakci zasláno 15. 2. 2016 / upravená verze obdržena 6. 7. 2016 / \\ k uveřejnění přijato 17. 8. 2016
}

\begin{abstract}
Abstrakt: Cílem studie je představit a popsat nově se formující výzkumnou oblast označovanou jako analytika učení (learning analytics), která se zaměřuje na využití kvantitativních metod v rámci výzkumu učení (převážně) ve virtuálním prostředí. V první části příspěvku se věnujeme historickým kořenům analytiky ve vzdělávání a mapujeme různé inspirační zdroje, ze kterých analytika učení jakožto svébytná oblast výzkumů vychází a čerpá. Dáváme analytiku učení do souvislosti s příbuznými výzkumnými oblastmi v kontextu výzkumů technologiemi podporovaného učení (technology enhanced learning). Druhá část studie se zaměřuje na samotné vymezení analytiky učení a zpřesnění pojmů. Zároveň přibližuje a srovnává některé z užívaných konceptů (úrovně analytiky ve vzdělávání, proces analytiky učení). Třetí část prezentuje hlavní výzkumné směry analytiky učení, které lze identifikovat v doposud publikovaných odborných zdrojích.
\end{abstract}

Klíčová slova: analytika učení, e-learning, virtuální vzdělávací prostředí, metodologie

Zrod analytiky učení jako relativně svébytné oblasti, která se zabývá zkoumáním učení ve virtuálním prostředí, bývá kladen do roku 2010 (Ferguson, 2012a). Tehdy Siemens (2010) publikoval na svém blogu definici analytiky učení, jež pak byla v upravené podobě v roce 2011 využita na první mezinárodní konferenci ${ }^{2}$ zaměřené specificky na analytiku učení. Později byla tato definice citována v několika odborných textech (Ferguson, 2012a; Chatti et al., 2012; Siemens, 2013), čímž se postupně stala obecně přijímanou jako základní vymezení této výzkumné oblasti. V roce 2011 byla také založena společnost pro výzkum analytiky učení (Society for learning analytics research) a analytika učení byla poprvé zmíněna ve výroční zprávě Horizon

1 Studie vznikla s podporou projektu Celoživotní učení $v$ institucionálních souvislostech (MUNI/A/1147/2015).

2 1st International Conference on Learning Analytics and Knowledge 2011. Více na webu konference (https://tekri.athabascau.ca/analytics/), kde je rovněž uvedena zmiňovaná definice analytiky učení. 
report (Johnson et al., 2011). Tak se tento pojem začal dostávat do širšího povědomí odborníků v kontextu e-learningu i vzdělávání obecně, což způsobilo, že se analytika učení v uvedené zprávě objevovala i v následujících letech jako jeden z klíčových trendů ve vzdělávání (Johnson et al., 2012, 2013, 2014). Od roku 2012 se pak na analytiku učení začaly zaměřovat i odborné časopisy a vzniklo tak několik speciálních čísel věnovaných tomuto tématu. ${ }^{3}$ V roce 2014 pak vychází první číslo nového časopisu zabývajícího se př́ímo analytikou učení (Journal of Learning Analytics) a vychází také první monografie na toto téma s názvem Learning analytics: From research to practice (Larusson \& White, 2014).

Jak je vidět $\mathrm{z}$ tohoto krátkého přehledu, jde o poměrně mladou oblast zkoumání, která si stále hledá místo na mapě pedagogických věd a v metodologii pedagogického výzkumu. ${ }^{4}$ Cílem této studie je proto zmapovat a představit analytiku učení jakožto jeden z nových výzkumných př́stupů ke studiu učení primárně ve virtuálním prostředí. Vzhledem k novosti analytiky učení zároveň považujeme za nejvhodnější formát přehledovou studii, která nám umožňuje nejen shrnout dosavadní směry empirických výzkumů, nýbrž také nastínit základní východiska formující se disciplíny a představit hlavní teoretické koncepty. Ze stejného důvodu byly do výběru zařazeny primárně zdroje, jež explicitně pracují s pojmem analytika učení, protože právě tyto zdroje lze považovat za určité ,jádro“ vznikající odborné komunity i za základ tohoto výzkumného přístupu. Konkrétně jde o následující zdroje:

- Sborníky z prvních čtyř ročníků konference Learning Analytics and Knowledge

- Speciální čísla časopisů Journal of Educational Technology \& Society, Journal of Asynchronous Learning Networks a American Behavioral Scientist, která byla věnována tématu analytiky učení;

- První 3 čísla časopisu Journal of Learning Analytics;

- Monografie Learning Analytics: From Research to Practice.

3 Jedná se o následující čísla časopisů: Journal of Educational Technology \& Society, 15(3), Journal of Asynchronous Learning Networks, 16(3) a American Behavioral Scientist, 57(10).

4 Na druhou stranu je nutno doplnit, že na některých univerzitách už se analytika učení začíná vyučovat jako samostatný obor (viz např. http://www.tc.columbia.edu/humandevelopment/learning-analytics/).

5 První a druhý ročník nesl název International Conference on Learning Analytics and Knowledge, od třetího ročníku se název ustálil na International Learning Analytics and Knowledge Conference (zkráceně LAK). 
Na jiné zdroje jsme se obraceli tehdy, pokud byly citovány ve výše uvedených zdrojích. V určitých případech využíváme i publikace určené pro širší odborné publikum či účelové publikace (např. přehledové či výroční zprávy apod.). Analytika učení se stále formuje, proto hrají také tyto zdroje důležitou roli např. při vymezování některých konceptů či zpřesňování terminologie. Při výběru těchto textů jsme se řídili tím, zda a jak často byly ty to zdroje citovány ve zdrojích tvořících zmiňované „jádro“ výzkumné oblasti.

V českém pedagogickém kontextu je téma analytiky učení zatím stále poměrně nové, takže neexistují žádné publikované studie, které bychom mohli zahrnout do přehledu. Přesto stojí alespoň za zmínku, že se již toto téma začíná objevovat na českých pedagogických konferencích, o čemž svědčí např. referáty Juhaňáka $(2013,2014)$ či Mareše (2015).

\section{Inspirace a východiska analytiky ve vzdělávání}

Analytiku jako obecný pojem je poměrně obtížné přesně vymezit. S tím, jak se tento pojem v průběhu posledních patnácti až dvaceti let dostal do širšího povědomí, začal být používán $\mathrm{v}$ mnoha různých oblastech a kontextech (Van Barneveld, Arnold, \& Campbell, 2012). Pojem analytika tak najdeme nejen ve spojení s učením (learning analytics), ale také např. ve spojení se zdravím (health analytics). Časté je také rozlišování analytiky podle účelu prováděných analýz (např predictive analytics či action analytics) nebo na základě spojení s konkrétní sadou nástrojů (Google analytics, Facebook analytics apod.). Někteří autoři se proto přiklánějí k názoru, že kvůli nadužívanosti tohoto pojmu je jakýkoli pokus o podání jeho dostatečně podrobné a netriviální definice předem odsouzen k nezdaru (Cooper, 2012a).

Pro účely této studie využíváme obecně pojatou definici autorek Bienkowské, Fengové a Meansové (2012), které vymezují analytiku v širokém smyslu jako využívání technik z počítačových věd, matematiky a statistiky pro extrakci užitečných informací z velkých objemů dat. Všimněme si přitom tří zásadních aspektů: (1) Analytika stojí na spojení znalostí a dovedností jak z oblasti informatiky (tj. obvykle nějaká forma programování), tak z oblasti statistické analýzy dat. (2) Cílem analytiky je získat informace, které pro nás budou užitečné při dalším plánování či jednání. Jde tedy o informace, které vedou k nějaké další akci (Cooper, 2012a). Van Barneveld a kol. (2012) dokonce vyzdvihují pouze tento aspekt a definují analytiku jednoduše jako daty řízené 
rozhodování (data-driven decision making). (3) V rámci analytiky se obvykle pracuje s velmi velkými objemy dat, nejsou neobvyklé ani datasety o desítkách či stovkách milionů záznamů.

Do širšího povědomí se pojem analytika zřejmě dostal především na základě dvou oblastí: webové analytiky (web analytics) a podnikové analytiky (business analytics). Z nich zároveň čerpaly další specifické oblasti analytiky při vlastním vzniku a formování. Není proto divu, že i u analytiky učení uvádějí mnozí autoři právě tyto dvě oblasti jako jedny z hlavních historických kořenů (např. Cooper, 2012b; Ferguson, 2012a, 2012b; Macfadyen \& Dawson, 2012; Shum, 2012).

Webová analytika se objevila hned po samotném vzniku a rozšíření webu, kdy jej postupně začaly využívat nejrůznější firmy ke svému podnikání. Ukázalo se totiž jako užitečné (tj. výdělečné) sledovat návštěvnost stránek, jakým způsobem se na nich uživatelé pohybují či jak je využívají. Na základě takto získaných znalostí mohli obchodníci nechat své stránky upravit a optimalizovat, což jim následně přinášelo větší zisky. Webová analytika se tak ustanovila jako oblast zabývající se sběrem, měřením, analýzou a vyhodnocováním webových dat za účelem porozumění chování uživatele a optimalizace webových stránek (Kaushik, 2011). Jakmile se pak nějaká forma online vzdělávání stala přinejmenším v oblasti vysokých škol více či méně běžným standardem, ${ }^{6}$ začala se nabízet zřejmá analogie. Stejně jako je využívána analytika ve firemní sféře pro zvýšení zisků, dalo by se jí zřejmě využít pro analýzu a optimalizaci online vzdělávacích prostředí a $\mathrm{v}$ důsledku toho pro zlepšení edukačního procesu. Jedním z hlavních pramenů analytiky učení je tak myšlenka aplikace webové analytiky ve specifickém kontextu online vzdělávacích systémů založených na webových technologiích.

Stejně výrazným příspěvkem do formování analytiky učení však byla i zmiňovaná podniková analytika. Jde o oblast $\mathrm{v}$ podnikové sféře, kterou můžeme i v česky psaných textech nalézt spíše pod označením Business Intelligence (BI). Na rozdíl od webové analytiky, která se zabývá specifickou oblastí analýzy provozu webových stránek, v rámci BI jde o širší využití analytiky pro

\footnotetext{
Ferguson (2012a) se odkazuje na výzkum uvádějící, že mezi lety 1994-2003 se využívání systémů pro řízení výuky vzdělávacími institucemi ve Velké Británii zvýšilo ze 7 \% na 85 \% Macfadyen a Dawson (2012) poukazují na podobná čísla v USA, kde od pozdních 90. let minulého století $93 \%$ vzdělávacích institucí výrazně investovalo do zavedení nějakého webového systému pro řízení výuky.
} 
zvýšení efektivity (převážně) interních firemních procesů a o podporu strategického managementu a rozhodování. Tento směr využití analytiky je dokonce starší než webová analytika jako taková. A rovněž v kontextu vzdělávání se uvažování o analytice ubíralo nejprve tímto směrem. Nešlo však ještě o analytiku učení (learning analytics), nýbrž o akademickou analytiku (academic analytics). Goldstein a Katz (2005) tak hovoří o akademické analytice jako o využití BI v akademickém sektoru za účelem zlepšení organizačních procesů a zvýšení efektivity v rámci univerzity. Podobně Fritz (2011) přibližuje akademickou analytiku jako oblast zabývající se primárně administrativními a provozními záležitostmi, jako jsou například rozpočet a plánování, obchod, finance a fundraising, řízení lidských a jiných zdrojů, správa institucionálního výzkumu a jiné akademické záležitosti.

Vidíme tedy, že obě zmíněné oblasti využití analytiky ve firemní sféře daly zároveň vzniknout dvěma různým směrům využití analytiky ve vzdělávání. Na jedné straně analytika učení inspirovaná primárně webovou analytikou a zaměřující se na samotné procesy učení a vyučování, na druhé straně akademická analytika vycházející z podnikové analytiky a související především s problematikou řízení vzdělávacích institucí.

Vedle výše uvedených disciplín však můžeme identifikovat ještě několik dalších oblastí výzkumné činnosti, které se významně podílely na vzniku a formování analytiky učení. Předně je nutno uvést oblast data miningu, jež se do češtiny někdy překládá jako dolování (z) dat. Vliv tohoto směru výzkumu na analytiku učení je tak silný, že je napříč autory z obou oblastí vesměs všeobecně přijímán (srov. např. Ferguson, 2012a, 2012b; Macfadyen \& Dawson, 2012; Romero \& Ventura, 2013). Siemens (2013) pak tentýž proud označuje jako dobývání znalostí z databází (knowledge discovery in databases). Obecně se data mining zabývá objevováním nových a potenciálně užitečných informací ve velkých objemech dat (Baker \& Yacef, 2009). Specificky v kontextu vzdělávání se přitom v posledních letech hovoří o dílčím výzkumném poli, které je označováno jako data mining ve vzdělávání (educational data mining - EDM). Jeho cílem je rozvoj data miningových metod a jejich aplikace na specifické typy dat pocházejících ze vzdělávacího prostředí za účelem zkoumání pedagogických otázek (Baker \& Yacef, 2009; Romero \& Ventura, 2013). Díky tomu, že se oblast EDM začala formovat o několik let dříve než analytika učení, výrazně ovlivnila i její vznik a další vývoj. Dokonce i oblasti zájmu obou disciplín se do značné míry překrývají, proto mnozí autoři usilují o jejich přesnější rozlišení. Podrobné srovnávání těchto oblastí však již sahá 
výrazně za rámec naší studie. Sdílíme názor těch autorů, kteří považují analytiku učení za širší oblast než EDM, protože analytika učení doplňuje oblast EDM o další metody a techniky čerpané z jiných oborů jako např. pedagogiky, sociologie či psychologie (Bienkowski et al., 2012; Siemens, 2013; Romero \& Ventura, 2013).

Další výzkumná oblast, která se podílela velmi výrazně na formování analytiky učení (srov. Ferguson, 2012a, 2012b; Chatti et al., 2012; Siemens, 2013), vychází z problematiky modelování uživatelu (user modeling). Jde o oblast výzkumů v rámci multidisciplinárního oboru studujícího interakci mezi člověkem a počítačem. ${ }^{7}$ Cílem je porozumění tomu, jak různí uživatelé interagují s určitou aplikací či rozhraním. Poté následuje vytvoření modelu, na jehož základě by bylo možné automaticky reagovat různým způsobem na různé způsoby interakce uživatelů s daným rozhraním. Např. tím, že se vzhled aplikace přizpůsobí podle potřeb uživatele, nebo se mu naopak doporučí nějaký relevantní související obsah apod. Dủležitý vliv modelování uživatelů na analytiku učení můžeme vidět také $\mathrm{v}$ tom, že vedle vlastního modelování uživatelů jsou uváděny ještě další tři oblasti, které jsou na modelování uživatelů postaveny (Siemens, 2013). Konkrétně jde o oblast kognitivního modelování (cognitive modeling), jež usiluje o modelování lidských kognitivních procesů, lidského rozhodování a řešení problémů. Asi nejvíce je kognitivní modelování využíváno $\mathrm{v}$ rámci oboru umělé inteligence, v kontextu vzdělávání je spojeno spíše s problematikou tzv. inteligentních tutorů či inteligentních tutorských systémů (intelligent tutoring system), které mají za cíl vedení žáka či studenta v průběhu učení s pomocí okamžité (automatické) a zároveň personalizované zpětné vazby. Jako třetí oblast vycházející z modelování uživatelů pak Siemens zmiňuje adaptivní hypermédia (adaptive hypermedia). Ta spočívají v personalizaci a adaptaci výukového obsahu na základě potřeb studenta či žáka. ${ }^{8}$ Zásadní důležitost rozsáhlé oblasti uživatelského modelování pro analytiku učení přitom vidí autoři (srov. Chatti et al., 2012; Siemens, 2013) v tom, že určitá forma modelování uživatelů se vesměs stala její inherentní součástí. Mnoho projektů a výzkumů v oblasti analytiky učení tak nějaký aspekt modelování uživatelů zahrnuje.

\footnotetext{
V angličtině se pro tento obor vžilo označení Human-Computer Interaction (HCI), do češtiny se tento termín překládá jen velmi zř́íka.

8 Chatti a kol. (2012) zmiňují ještě oblasti personalizovaného adaptivního učení (personalized adaptive learning) a doporučovacích systémů (recommender systems), které opět vychází $\mathrm{z}$ uživatelského modelování.
} 
Co se týče metodologických inspirací z oblasti pedagogiky, upozorňují Chatti a kol. (2012) především na výrazné styčné plochy mezi analytikou učení a akčním výzkumem. Základní charakteristiky akčního výzkumu (action research) a analytiky učení jsou totiž dle Chattiho velmi podobné. Akční výzkum se zaměřuje na konkrétní školní situaci a často je prováděn samotnými učiteli. Jeho hlavním cílem je zdokonalování pedagogické praxe a zvyšování kvality práce učitelů, což má vést k celkovému zkvalitňování poskytovaného vzdělávání. Esenciální charakteristikou je tak zásah do dosavadní praxe. V průběhu akčního výzkumu proto dochází k zavádění určitých změn. Prováděné intervence mají přitom cyklický charakter, kdy je každá z intervencí nejprve vyhodnocena a teprve poté je stanovován další postup výzkumu. Průběh akčního výzkumu tak bývá často konceptualizován v podobě iterativního cyklu (Nezvalová, 2003). Stejně tak postup v analytice učení bývá pojímán jako opakující se cyklus (viz níže) zahrnující průběžné intervence a zavádění změn. Podobně je cílem analytiky učení zlepšení a zkvalitnění edukační praxe.

Přesto můžeme mezi akčním výzkumem a analytikou učení nalézt i několik zásadních rozdílů. Zatímco na akčním výzkumu často participují především učitelé a studenti, resp. žáci, výzkumné projekty založené na analytice učení často zahrnují více zúčastněných stran (např. vedení instituce, technické oddělení instituce apod.). Chatti a kol. (2012) zmiňují také rozdíl v tom, čím vlastně samotný výzkumný projekt začíná. U akčního výzkumu jde obvykle o problémy či otázky, které vyplývají z vlastní pedagogické praxe. Výzkumné projekty v rámci analytiky učení se naopak formují často až na základě pozorování a analyzování již získávaných dat. $\mathrm{V}$ neposlední řadě se analytika učení a akční výzkum odlišují v samotných výzkumných metodách a postupech, které používají. Zatímco $\mathrm{v}$ akčním výzkumu je běžnější použití kvalitativních metod, analytika učení stojí téměř výhradně na metodách kvantitativních.

V neposlední řadě je třeba spolu se Siemensem (2013) zmínit jako důležitý zdroj mnoha inspirací pro analytiku učení celou oblast e-learningu či technologiemi podporovaného učení. A to ve smyslu, který v českém kontextu zastávají autoři této studie (Zounek, 2009; Zounek et al., 2016), když vymezují e-learning jako širokou oblast jak teoretického studia a empirických výzkumů, tak i reálných vzdělávacích procesů spočívajících v práci s informačními a komunikačními technologiemi (ICT). Jednak totiž obrovské rozšířcní a reálné využívání ICT ve výuce vůbec umožnilo analytiku učení a bylo zásadním impulsem pro její vznik, jednak široké spektrum provedených výzkumů 
v oblasti e-learningu přispělo $\mathrm{k}$ její metodologické bázi a ovlivnilo směr dalšího zaměřování pozornosti výzkumníků při využívání analytiky učení.

\section{$2 \quad$ Vymezení a konceptualizace analytiky učení}

Vyjdeme-li ze všeobecně přijímané definice zmiňované v úvodu, můžeme analytiku učení vymezit jako disciplínu zabývající se „měřením, sběrem, analýzou a reportováním dat o studentech a jejich kontextu za účelem pochopení a optimalizování učení a prostředí, ve kterém učení probíhá" (Long \& Siemens, 2011). Vidíme, že tato definice poměrně zřetelně navazuje na tradici webové analytiky, když se zaměřuje přímo na vzdělávací prostředí a jeho optimalizaci. Na druhou stranu odhlíží od technických specifik a zdůrazňuje výhradně pedagogickou stránku. Všimněme si také, že nespojuje analytiku učení pouze s oblastí e-learningu či učením v online prostředí, jako to dělají jiní autoři. Např Chatti a kol. (2012) definují analytiku učení velmi podobně jako výzkumnou oblast zaměřující se na rozvoj metod analýzy dat ze vzdělávacího prostředí a využití těchto metod k podpoře učení. Chápou ji ovšem jako dílčí výzkumnou oblast v rámci e-learningu. ${ }^{9}$ Podobně Ferguson (2012a) zastává stanovisko, že analytika učení se týká výhradně učení v online prostředí. Domníváme se však, že takové pojetí analytiky učení je př́liš úzké. Je to z toho důvodu, že se doposud zřejmě největší pozornost ubírala na analytiku učení v online vzdělávacích systémech, což je dáno jednoduše tím, že právě v těchto systémech jsou již nyní uchovávány velké objemy dat, které je možné analyzovat. Nicméně stejně dobře je možné aplikovat analytiku učení na data, která pochází z reálného vzdělávacího prostředí, nikoli virtuálního. ${ }^{10}$ Proto považujeme za vhodnější přiklonit se $\mathrm{k}$ Siemensovu pojetí.

Siemensova definice však postihuje pouze jednu z úrovní, o kterých se uvažuje v souvislosti s analytikou ve vzdělávání. Podíváme-li se na členění analytiky učení, které navrhuje Shum (2012), můžeme identifikovat tři základní úrovně analytiky ve vzdělávání:

Chatti a kol. (2012) sice nepoužívají přímo termín e-learning, nýbrž technologií podporované učení (technology enhanced learning), v daném kontextu jde však o totéž.

10 Zatím se sice mnoho takových typů dat systematicky neshromažd'uje a neanalyzuje, lze ale předpokládat, že zvláště s postupujícím rozvojem mobilních a nositelných technologií (wearable technology) ve vzdělávání se množství dostupných dat tohoto typu začne rapidně zvyšovat. 
- Mikroúroveň se zaměřuje na individuální studenty či skupiny studentů. ${ }^{11}$ Na této úrovni jde o sběr a interpretaci dat, která za sebou nechávají jednotliví uživatelé při používání různých systémů či služeb. Nejčastěji jde o záznamy ze vzdělávacích informačních systémů (EIS) zahrnujících nap̌r. absolvované předměty či získané známky a o záznamy aktivit studenta v online výukovém prostředí (LMS), které umožňují zjistit, které studijní materiály si student zobrazil, jak dlouho mu trvalo nějaké cvičení apod. Může však jít i o další typy dat týkajících se studenta, např:: výpůjčky v knihovně, sociální sít' kontaktů, záznamy o pohybu studenta získané pomocí geolokace aj. Výsledky analýz na mikroúrovni jsou př́nosné především pro učitele. Mohou však být užitečné i pro samotné studenty, jimž dokážou poskytovat vhled do vlastních (třeba neuvědomovaných) učebních návyků, a podporovat tak reflexi vlastního učení.

- Mezoúroveň je úrovní jednotlivých vzdělávacích institucí, kde je hlavním cílem analytiky optimalizace administrativních a organizačních procesů v rámci vzdělávací instituce. Data zde pocházejí primárně z nejrůznějších ekonomických, správních či manažerských systémů. Často však bývají doplňována o data z dalších specifických systémů, které daná instituce využívá. $V$ př́ípadě univerzit jsou to zvláště systémy schraňující data o výzkumné a publikační činnosti apod. Výsledky analytiky na mezoúrovni mohou být přínosné především pro administrativu, management a vedení vzdělávací instituce, ale i pro investory/donátory a další zainteresované strany.

- Makroúroveň pak odpovídá regionální, státní, národní či mezinárodní úrovni. Zde se dostáváme na meziinstitucionální úroveň, kde by analytika mohla hrát roli jednak pro jednotlivé vzdělávací instituce, jednak pro nejrůznější regionální a státní školské orgány, národní vlády či mezinárodní organizace.

Na základě výše uvedeného členění analytiky ve vzdělávání je patrné, že Siemensem navrhovaná definice odpovídá mikroúrovni. Je proto nutné rozlišovat užší a širší význam pojmu analytika učení. V užším významu se pohybujeme pouze na mikroúrovni, $\mathrm{v}$ širším významu pod tento pojem spadají všechny uvedené úrovně. Považujeme za vhodnější oba významy explicitně rozlišovat (např. analytika učení vs. analytika vzdělávání, jak to činíme v této

11 Hovoř́me zde sice primárně o studentech, uvedené se však může týkat i žáků. 
studii). V dosavadních zdrojích však toto rozlišení není důsledně dodržováno a často se tak využívá pouze označení analytika učení (learning analytics).

Zároveň vidíme, že mezoúroveň do značné míry odpovídá tomu, co bylo výše identifikováno jako jedna ze souvisejících oblastí, totiž akademická analytika. Stejně tak Long a Siemens (2011) rozlišují mezi akademickou analytikou a analytikou učení právě na základě toho, že akademická analytika se zaměřuje na úroveň institucí a výše (tj. mezoúroveň plus makroúroveň), zatímco analytika učení zahrnuje úroveň jednotlivých kurzů (tj. mikroúroveň). $V$ takovém př́́padě můžeme analytiku vzdělávání (tj. analytiku učení v širokém smyslu) chápat jako spojení analytiky učení v úzkém smyslu a akademické analytiky. ${ }^{12}$

\subsection{Dimenze analytiky učení}

Nyní se zaměříme na podrobnější rozpracování konceptu analytiky učení. Vycházíme zde z obecného rámce Grellera a Drachslera (2012), který zahrnuje šest základních dimenzí rozčleněných na další suboblasti.

12 Nutno ovšem doplnit, že výše uvedené pojmy a jejich rozlišení není zatím široce ukotveno a je možné, že se bude postupem času dále měnit, zpřesňovat či rozšiřovat. Např. označení „akademická analytika“ jasně odkazuje k místu svého vzniku, totiž akademickému prostředí univerzit. Lze ovšem očekávat rozšíření analytiky i mimo univerzitní prostředí, proto je možné, že se v budoucnu rozšśŕí obecnější pojem, který by nezahrnoval jen akademickou sféru (napřs. institucionální analytika). Jinou možností je, že využívání analytiky na středních a základních školách bude mít svá výrazná specifika, a tudíž se vedle akademické analytiky prosadí zcela nové označení pro analytiku na SŠ či ZŠ. 


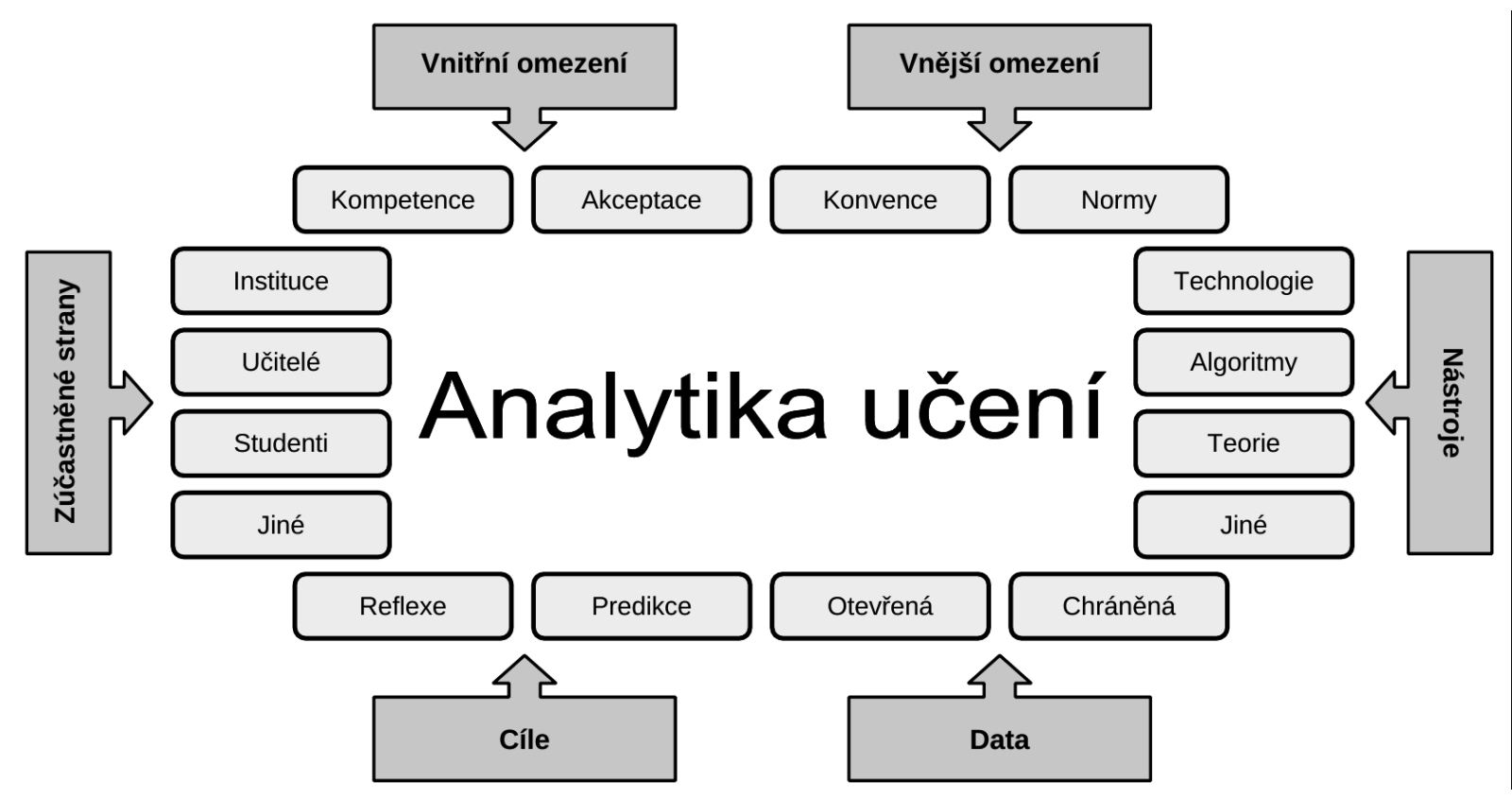

Obrázek 1. Obecný rámec tvořící šest základních dimenzí analytiky učení (upraveno podle Greller \& Drachsler, 2012).

První dimenzi tvoří různé zúčastněné strany. Jak bylo naznačeno již dř́ve, u analytiky učení můžeme vždy rozlišovat několik zúčastněných stran od studentů přes učitele až po vedení instituce či jiné zúčastněné strany (např. investory, donátory, grantové agentury). To, které zúčastněné strany jsou v konkrétním případě zapojeny, samozřejmě následně ovlivňuje zbývající dimenze analytiky učení.

Smyslem analytiky učení je dle Grellera a Drachslera (2012) odhalování skrytých informací a souvislostí ve vzdělávacích datech a jejich následné zpracování (napřr v podobě vizualizace) pro různé zúčastněné strany. Autoři zde přitom rozlišují dva základní cíle: reflexi a predikci. Reflexí je míněna především sebe-evaluace. Analytika učení zde má být prostředkem k získání lepšího vhledu do vlastního jednání. Například pomocí určitého nástroje můžeme vizualizovat chování studentů či učitelů v online kurzu, což jim dá možnost reflektovat, zda jejich učení, resp. vyučování probíhá podle jejich představ a zejména cílů. Predikce se pak nachází ještě o krok dál, kdy analytika učení spočívá v modelování chování studentů, což umožňuje např. upozorňovat učitele konkrétně na ty studenty, kteří mohou mít na základě odpovídajícího modelu určitý problém se studiem. Učitel tak má podklady k tomu, 
aby mohl např. s daným studentem pracovat individuálněji nebo mu mohl nabídnout jinou formu podpory při učení, a zabránil tak neúspěchu studenta na konci kurzu.

Další základní dimenzí analytiky učení jsou získaná a analyzovaná data. V rozlišení dimenze na otevřená a chráněná data přitom můžeme spatřovat zřetelný důraz autorů na etické aspekty práce s daty (jaká data o studentech jsou sbírána, jak jsou uchovávána, komu jsou zpř́stupňována apod.).

Mezi nástroje zahrnují autoři nejen samotné technologie a konkrétní technická řešení, ale také využité algoritmy a metody analýzy, dokonce i celé teorie a teoretické přristupy. Některé konkrétní nástroje budou zmíněny níže.

Vnější omezení jakožto dimenzi analytiky učení rozdělují Greller a Drachsler (2012) na konvence, pod které zahrnují především etiku, a normy, jež spojují s právem a konkrétní legislativou. Vždy se samozřejmě pohybujeme v určitém společenském kontextu, na který musí být brán ohled. Při využití analytiky ve vzdělávacím kontextu je však specifické to, že mnoho etických i právních otázek zatím nebylo díky novosti problematiky ani položeno, natož zodpovězeno.

Vnitřní omezení vycházejí z možností, limitů a zdrojů instituce, která chce analytiku učení využívat. Zásadní je zde oblast kompetencí, jelikož kvůli své multidisciplinární povaze vyžaduje analytika učení pro své efektivní fungování jejich nové typy (zde především v souvislosti s moderními technologiemi - programování, pokročilá analýza dat apod.). Nedílnou součástí je pak i akceptace analytiky učení napříč zúčastněnými stranami.

\subsection{Proces analytiky učení}

Zatímco $\mathrm{v}$ předchozí části byl nastíněn obecný rámec, nyní obrátíme pozornost na procesní stránku analytiky učení. Jak bylo již naznačeno v pasáži o akčním výzkumu, analytika učení, podobně jako akční výzkum, bývá konceptualizována $\mathrm{v}$ podobě opakujícího se cyklu obsahujícího několik fází. Není však zatím obecně přijímáno jedno pojetí a vnímání jednotlivých fází se tak u různých autorů liší. Tak např́klad Campbell a Oblinger (2007) představili cyklus akademické analytiky v pěti krocích zahrnujících získávání dat, informování, predikování, jednání a následné zlepšování. Chatti a kol. (2012) později zúžili počet etap jen na tři (viz tabulka 1), zatímco Siemens (2013) naopak uvádí cyklus až o sedmi fázích. Lal (2014) se pak pokouší 
o sjednocení předchozích přístupů a uvádí fází šest. Srovnání zmíněných pojetí procesu analytiky učení je možné vidět v tabulce 1 .

Tabulka 1

Srovnání různých konceptualizací procesu analytiky učení

\begin{tabular}{|c|c|c|c|}
\hline Campbell a Oblinger (2007) & Chatti a kol. (2012) & Siemens (2013) & Lal (2014) \\
\hline \multirow{4}{*}{ získávání } & \multirow{4}{*}{$\begin{array}{l}\text { sběr dat } \\
\text { a předzpracování } \\
\text { (pre-processing) }\end{array}$} & sběr a akvizice & \multirow{2}{*}{ získávání dat } \\
\hline & & ukládání & \\
\hline & & čištění & \multirow{2}{*}{$\begin{array}{l}\text { strukturování } \\
\text { a agregování dat }\end{array}$} \\
\hline & & integrace & \\
\hline informování & \multirow{3}{*}{ analýzy a akce } & analýza & analyzování \\
\hline predikování & & $\begin{array}{l}\text { zobrazení } \\
\text { a vizualizace } \\
\end{array}$ & $\begin{array}{l}\text { zobrazování } \\
\text { a vizualizace }\end{array}$ \\
\hline jednání & & & akce \\
\hline zlepšování & $\begin{array}{l}\text { následné zpracování } \\
\text { (post-processing) }\end{array}$ & akce & zlepšování \\
\hline
\end{tabular}

Nepřikláníme se zde ani $\mathrm{k}$ jednomu z uvedených modelů, ale pokusíme se proces analytiky učení popsat ve čtyřech základních krocích:

1) Sběr a zpracování dat samozřejmě záleží na tom, co je $v$ daném případě naším cílem a jaké otázky si pokládáme. Campbell a Oblinger (2007) uvádějí poměrně rozsáhlý výčet typů dat, která mohou být ve vzdělávacích institucích dostupná - od demografických dat přes výsledky studia až po chování žáků či studentů v konkrétních kurzech. Pozornost je však nutné věnovat i tomu, která data zatím sbírána nejsou, ale mohla by být pro naše účely potenciálně užitečná. Získaná data je následně nutné předzpracovat a př́ípadně převést do potřebných formátů. Stěžejní roli zde hraje čištění dat. Pro komplexnější pohled na zkoumaný fenomén mủže být využita integrace dat z několika různých zdrojů (Siemens, 2013).

2) Analýza a vizualizace je druhou fází analytického procesu. $V$ této fázi jsou používány různé metody a techniky zkoumání získaných dat, a to za účelem objevení potenciálně užitečných informací a jejich následné prezentace (často v podobě vizualizace) zúčastněným stranám. Co se týče využívaných metod, Lal (2014) je rozděluje do tří základních oblastí: (a) základní statistické metody, (b) data miningové metody, v nichž jde především o klasifikaci, klastrování a asociační pravidla; (c) metody 
sociální analytiky učení, kam lze zařadit např. analýzy sociálních sítí, obsahovou analýzu či analýzy diskurzu.

3) Akce zde znamená zásah do edukační reality, který je proveden určitou zainteresovanou stranou na základě výsledkủ analýz, jež jí byly prezentovány. Akce přitom může mít nejrůznější charakter. Může jít o jednoduché oznámení, upozornění či varování, ale také o komplexnější formu intervence do současné podoby edukační reality. Tak může být např́ílad žák či student automaticky upozorněn na to, že v porovnání s ostatními je výrazně pozadu. Anebo může být naopak upozorněn učitel, který následně sám zvolí vhodný způsob intervence. Akcí může být také optimalizace stávajícího výukového systému či jiné systémové úpravy či vylepšení. $V$ př́ípadě adaptivních systémů lze za akci považovat přizpưsobení či personalizaci, která je vykonána na základě výsledku provedených analýz. U doporučovacích systémů lze za akci považovat automatické doporučení vhodného rozšiřujícího studijního materiálu (Chatti et al., 2012; Lal, 2014; Siemens, 2013).

4) Reflexe a revize označují poslední etapu cyklu, v níž probíhá zhodnocení či evaluace provedené akce a zároveň plánování dalšího cyklu. Může tak jít napřs. o sběr dalších dat nebo doplnění stávajících, provedení doplňujících analýz či volba jiných analytických metod, vykonání jiných akcí apod. (Campbell \& Oblinger, 2007; Chatti et al., 2012).

\section{$3 \quad$ Výzkumné směry a témata analytiky učení}

Podíváme-li se na přehled výzkumných směrů, kterým je v analytice učení věnována hlavní pozornost, můžeme je seskupit pro názornost do čtyř hlavních oblastí. Zároveň je ovšem nutné podotknout, že je v rámci těchto směrů patrný i určitý vývoj. Zatímco v počátcích bylo množství výzkumů a publikací spojeno s vývojem konkrétních nástrojů (spíše jednodušších deskriptivních), postupně se pozornost přesouvala ke složitějším prediktivním nástrojům a k hledání možných prediktorů (ne)úspěchu ve studiu obecně. Současně si mnozí autoři začali uvědomovat širší souvislosti fenoménu učení a snaží se proto zaměřit zvláště na jeho sociální aspekty. V poslední době pak také sílí důraz na etické aspekty analytiky ve vzdělávání, kterým v počátcích byla pozornost věnována spíše sporadicky. V následující části se proto budeme podrobněji věnovat výše naznačeným čtyřem oblastem, do nichž lze výzkumná témata analytiky učení rozčlenit. 


\subsection{Analytické nástroje pro sumarizaci a vizualizaci dat}

Výše naznačovaná praktická či aplikační orientace analytiky učení je na první pohled zřejmá, když si uvědomíme, že velké množství výzkumů a publikací $v$ této oblasti je spojeno $s$ vývojem nějakého konkrétního analytického nástroje. $\mathrm{V}$ tabulce 2 jsou pro přehled uvedeny analytické nástroje, jež byly $\mathrm{v}$ posledních několika letech často zmiňované.

Tabulka 2

Vybrané analytické nástroje

- AAT - Academic Analytics Tool (Graf et al., 2011)

- CMA - Check My Activity (Fritz, 2011)

- Cohere (De Liddo et al., 2011)

- EIWM - E-learning Web Miner (Garciá-Saiz \& Zorilla, 2011)

- eLAT - exploratory Learning Analytics Toolkit (Dyckhoff et al., 2012)

- GLASS - Gradient's Learning Analytics System (Leony et al., 2012)
- Meerkat-ED (Rabbany et al., 2014)

- NAT - Network Awareness Tool (Schreurs \& De Laat, 2012)

- OU Analyse (Kužílek et al., 2015)

- SAM - Student Activity Meter (Govaerts et al., 2012)

- Course Signals (Arnold \& Pistilli, 2012)

- SNAPP - Social Networks Adapting Pedagogical Practice (Dawson, Bakharia, \& Heathcote, 2010)

- StepUp! (Santos et al., 2012)

Primárním cílem těchto nástrojů je sumarizování či vizualizace dat (nejčastěji) z různých online výukových prostředí (LMS/VLE). ${ }^{13}$ Jde přitom o nástroje poměrně různorodé, určené pro různé zúčastněné strany. Existují tak např. nástroje jako $C M A, S A M$ či StepUp!, které jsou určené pro studenty a které mají podporovat jejich reflexi vlastního procesu učení. Nástroje se tak snaží poskytnout studentům informace např. o tom, kolik času stráví studiem různých materiálů, jak si vedou s ohledem na doporučený studijní plán či v porovnání s jinými studenty apod. Na druhé straně jsou pak nástroje poskytující užitečné informace učitelům, např.: AAT, EIWM, eLAT či GLASS. Jde o nástroje, které mají vyučujícím pomoci „monitorovat“ chování studentů v online kurzech. Často prostřednictvím přehledné vizualizace aktivity studentů a jejich využívání výukového obsahu, příp. s možností srovnávání různých skupin studentů apod. Najdeme zde také nástroje jako Cohere, NAT či populární $S N A P P$, které se zaměřují na metody používané v tzv. sociální analytice učení (viz níže). Za explicitní zmínku pak stojí komplexní nástroj Meerkat-ED (určený zejména výzkumníkům), který může být poměrně snadno použit pro analýzu interakce studentů a učitelů v diskuzních fórech.

13 Zmiňované nástroje se často označují jako tzv. analytic dashboards. 


\subsection{Predikce (ne)úspěchu ve studiu}

Za centrální téma druhé oblasti výzkumů bychom mohli považovat snahu o predikci (ne)úspěchu studentů ${ }^{14} \mathrm{v}$ jejich studiu. Ačkoli může být prediktivní modelování v kontextu vzdělávání využito mnoha způsoby, v oblasti analytiky učení je v současnosti nejvíce využíváno pro výpočet pravděpodobnosti, zda konkrétní studenti budou schopni absolvovat kurz či dokončit studium. Tyto odhady se pak mohou použít pro efektivnější směrování intervence a podpory právě na „rizikové“ studenty ${ }^{15}$, kteří mají při studiu nějaké problémy (Clow, 2013). Velká část výzkumů se tak zaměřuje bud' výhradně na hledání co možná nejlepších prediktorů úspěšnosti, nebo zároveň i na vývoj systémů včasného varování (Early Warning Systems - EWS), jejichž cílem je co nejdříve identifikovat studenty, kteří mají při studiu nějaký problém, a př́ípadně rovnou upozornit vyučující, jež se pak mohou rozhodnout, jak tuto situaci řešit.

V literatuře asi nejčastěji zmiňovaným př́kladem takových systémů je nástroj Course signals, vyvinutý na Purdue University. Nástroj se zaměřuje na predikci (ne)úspěšnosti studentů $v$ daném online kurzu. $Z$ pohledu uživatele se přitom může zdát poměrně triviální, jelikož jeho základní funkcí je pro každého studenta kurzu zobrazit jednu z barev semaforu: červenou v př́padě vysoké pravděpodobnosti, že student kurz nedokončí, žlutou značící možné problémy a zelenou signalizující vysokou šanci na úspěšné dokončení kurzu. Za touto jednoduchou vizualizací se však skrývá poměrně komplexní výpočet kombinující čtyři různé složky: (1) dosavadní výkon studenta v kurzu, (2) množství dosavadní interakce v LMS/VLE ve srovnání s ostatními účastníky kurzu, (3) předchozí studijní úspěšnost a (4) další (převážně demografické) charakteristiky studenta jako věk, trvalý pobyt apod. Dosavadní výsledky pak naznačují, že využití tohoto nástroje přispívá nejen k vyšší úspěšnosti studentů v jednotlivých kurzech, ale také ke snížení počtu studentů, kteří studium na univerzitě předčasně ukončí (Arnold \& Pistilli, 2012).

Jiným nástrojem podobného typu, který stojí za zmínku zvláště díky české stopě, je nástroj $O U$ Analyse, jenž je vyvíjen (převážně) českým týmem na Open University. Tento nástroj kombinuje demografické údaje o studentech s daty

14 Opět zde explicitně zmiňujeme pouze studenty, jelikož v současnosti je analytika učení realitou především na vysokých školách. Dá se ale předpokládat, že analytika učení se postupně bude rozšiřovat i na střední či dokonce základní školy, čímž by se pak výše uvedené týkalo i žáků.

15 „Rizikovými“ studenty zde (i níže) myslíme studenty či žáky, kterým z jakéhokoli důvodu hrozí, že nebudou schopni dokončit konkrétní kurz či studium obecně. 
o jejich aktivitě v LMS Moodle a pro identifikaci „rizikových“ studentů využívá hlasování čtyř různých prediktivních modelů (Kužílek et al., 2015). Vzhledem k omezenému prostoru nelze bohužel zmínit další výzkumy a nástroje z této oblasti. Na základně množství publikovaných studií je ale možné tuto oblast považovat v současnosti za asi nejvýznamnější.

\subsection{Sociální analytika učení}

Sociální analytika učení (social learning analytics) představuje do určité míry opoziční postoj vůči výše zmiňovaným přístupům orientovaným na identifikaci „rizikových“ studentů. Za hlavní proponenty tohoto směru výzkumu lze považovat dvojici autorů Shum a Ferguson (Shum \& Ferguson, 2012; Ferguson \& Shum, 2012), pro které je sociální analytika učení specifickou podmnožinou analytiky učení, jež vychází z pojetí učení jako sociálního procesu. Podle těchto autorů učení nemůže být dostatečně pochopeno, dokud se budeme soustředit na studenty pouze jako na jednotlivce a nebudeme brát zřetel na důležité aspekty jako interakce, spolupráce, skupinové procesy apod. Siemens (2012) se přidává k těmto hlasům, když zdůrazňuje nutnost přesunu pozornosti výzkumníků od identifikace „rizikových“ studentů směrem $\mathrm{k}$ jiným přístupům a metodám. Identifikace ohrožených studentů sice dle Siemense je a zůstane důležitým tématem na poli analytiky učení, okamžitě ale dodává že „identifikování ohrožených studentů je pouze malý aspekt toho, co analytika může udělat pro zlepšení vzdělávání" (Siemens, 2012).

Hlavním specifikem sociální analytiky učení jsou tak především metody výzkumu, které jsou využívány k zachycení sociálních aspektů učení. Přestože Ferguson a Shum (2012) zmiňují až pět různých metodologických rámců, ${ }^{16}$ stěžejní roli v dosavadních výzkumech hraje především analýza sociálních sítí (social network analysis - SNA) a různé verze automatizované analýzy textových dat. Baker a Inventado (2014) dokonce považují automatizovanou analýzu textových dat a analýzu diskurzu za hlavní metodologické oblasti, ve kterých se odlišuje analytika učení od data miningu ve vzdělávání. V oblasti analytiky učení jsou totiž tyto metody používány mnohem více.

Z výzkumů využívajících metody sociální analytiky učení lze uvést případovou studii Brookse, Greera a Gutwina (2014), kteří použili SNA k mapování aktivity studentů v online diskuzích fórech. Gašević, Zouaq a Janzen (2013)

16 Konkrétně jde o social network analytics, discourse analytics, content analytics, disposition analytics a context analytics. 
pak hledali s pomocí SNA vztah mezi sociálním kapitálem studentů a jejich studijními výsledky. Jiný zajímavý př́spěvek k metodologii SNA přidává Kim a Lee (2012), kteří zkoumají možnosti multidimenzionálního přístupu pro analýzu vztahů mezi jednotlivci v průběhu online interakce. Hecking, Ziebarth a Hoppe (2014) se snaží s pomocí SNA identifikovat různé způsoby využívání studijních materiálů v online kurzech. Za zmínku rovněž stojí práce de Laata a Schreurse (2013), kteří SNA spolu s dalšími metodami sociální analytiky učení využili v kontextu neformálního profesního rozvoje.

\subsection{Etické aspekty analytiky učení}

V neposlední řadě je nutné zmínit rodící se odbornou diskuzi na téma etických aspektů analytiky učení (Dringus, 2012; Ferguson, 2012a; Slade \& Prinsloo, 2013). Spolu s tím, jak se analytika učení dostává do širšího povědomí a jak různé analytické nástroje začínají být používány na mnoha vzdělávacích institucích, objevuje se množství etických otázek, kterým doposud nebyla věnována patřičná pozornost. Slade a Prinsloo (2013) poukazují na to, že mnoho studentů v současnosti zřejmě ani neví, jaká data o nich škola či univerzita sbírá a jak je př́́padně analyzuje. Nabízí se tudíž otázka, jestli by zde neměla být povinnost informovat studenty či od nich získávat informovaný souhlas, jako je zvykem u jiných typů výzkumů. Velmi užitečným materiálem je v tomto kontextu přehled literatury, který podává Sclater (2014) v souvislosti s tvorbou Kodexu praxe pro analytiku učení. Sclater zde identifikuje až 93 otázek, které si pokládají autoři snažící se vymezit základní etický rámec pro analytiku učení (zmiňme napřs: Kdo má vlastnit data, která jsou automaticky generována a následně uchovávána při používání různých vzdělávacích systémů? Má mít student možnost zakázat sběr a analýzu dat o své osobě? Kdo má mít přístup ke studentským datům? Má univerzita právo poskytovat data o studentech třetím subjektům?).

Má-li být analytika učení morální praxí, je nutné si tyto nové a doposud často nezodpovězené otázky začít klást. Zároveň je třeba si uvědomovat i možná rizika, která se s využíváním analytiky v kontextu vzdělávání mohou pojit. Na druhou stranu nelze asi než souhlasit s jedním z principů, který uvádějí Slade a Prinsloo (2013) při zvažování základního etického rámce pro analytiku učení: Vzdělávací instituce si nemohou dovolit nevyužívat dostupná data a analytické nástroje. Vzdělávací instituce mají zodpovědnost především vůči samotným studentům a žákům, a měly by proto využívat dostupná data k lepšímu pochopení jejich učení a ke zlepšování jejich výsledků. 


\section{Závěr}

Analytika učení představuje nový mezioborový přístup, který se teprve formuje a vyvíjí, ale již nyní se ukazuje jeho potenciál pro využití v pedagogice a pedagogické psychologii. V současnosti zatím zůstává množství otázek týkajících se toho, kam bude tento vývoj směřovat - zda se analytika učení postupem času stane svébytným výzkumným polem, nebo se její metody a techniky postupně stanou součástí příbuzných oblastí popsaných v první kapitole článku, či se dokonce zařadí mezi běžně používané metody pedagogického výzkumu. Není také prozatím jasné, jak velký dopad bude mít analytika učení na vzdělávání a učení obecně. Přitom právě změna, resp. zlepšení dosavadní výukové praxe je jedním z hlavních cílů analytiky učení, jak bylo zmíněno v souvislosti s akčním výzkumem.

Na některé z těchto otázek je však už nyní možné alespoň částečně odpovědět. At' už bude další vývoj jakýkoli, již v současnosti analytika učení nabízí příležitosti pro odborníky z oblasti pedagogiky. Existuje zde stále více se rozšiřující komunita výzkumníků z různých oborů, která rozvíjí poměrně nové výzkumné metody $\mathrm{v}$ kontextu vzdělávání. Zde pak vidíme hlavní metodologickou prŕležitost pro pedagogický výzkum. A to nejen $\mathrm{v}$ tom smyslu, že by metody a postupy analytiky učení mohly obohatit repertoár výzkumných metod pedagogických věd, ale také v obráceném směru. Dosavadní pedagogický výzkum spolu se svými metodami může být (a z našeho pohledu by i měl být) zásadním zdrojem inspirace pro další rozvoj analytiky učení. Za velkou příležitost považujeme především kombinaci „tradičních“ výzkumných metod s metodami analytiky učení.

Vidíme také, že se zájem odborné komunity postupně přesouvá od konkrétních technických řešení k problematice učení obecně, přičemž důležitou roli zde hraje sociální analytika učení zaměřující se na sociální aspekty učení. Nejde již tedy o výhradně technickou záležitost, nýbrž o výrazně širší oblast, která si klade ryze pedagogické otázky o tom, jak vlastně probíhá učení (zvláště, ale nikoli výhradně) v online prostředí. Lze proto očekávat, že postupem času se analytice učení bude věnovat stále více výzkumníků z oblasti pedagogiky, kteří se budou podílet na zodpovídání těchto otázek. Je zde totiž jasně patrný velký potenciál analytiky učení pro získání hlubšího vhledu do procesu učení. Velké objemy dat ze vzdělávacích a výukových systémů mohou při využití adekvátních metod poskytovat důležité informace o způsobech učení a vyučování v těchto systémech. 
Navíc se ukazuje, že téma analytiky učení se stále udržuje v centru pozornosti mnoha odborníků na e-learning a technologiemi podporované učení. Ilustrovat to lze mimo jiné na výroční zprávě Horizon report, kterou jsme zmiňovali již v úvodu. Analytika učení se v této zprávě objevovala jakožto jeden z klíčových trendů ve vzdělávání v letech 2011 až 2014 (viz Johnson et al., 2012, 2013, 2014). Následně v roce 2015 (viz Johnson et al., 2015) již jako jeden z hlavních trendů tato oblast uvedena nebyla, což mohlo naznačovat, že šlo jen o dílčí trend, který postupem času vymizel. V nové zprávě pro rok 2016 (viz Johnson et al., 2016), se však již analytika učení opět objevuje $\mathrm{v}$ rámci nejaktuálnějších trendů. Lze proto snad oprávněně usuzovat, že jde skutečně o významnou oblast zájmu (přinejmenším) v kontextu technologiemi podporovaného učení.

V neposlední řadě může být oblast analytiky učení zásadním impulzem k výraznějšímu zaměření pozornosti na etické aspekty související s využívaním analytiky (ale i ICT obecně) v každodenní pedagogické praxi. Ač to na první pohled nemusí být zcela zřejmé, s postupným zaváděním moderních technologických prostředků do kontextu vzdělávání se vynořují nejrůznější etické otázky, kterým mnohdy nebývá věnována patřičná pozornost. Domníváme se, že zvláště v kontextu vzdělávání nelze používat analytiku a jiné technologické prostředky bezhlavě a bez uvažování nad širšími souvislostmi. Zároveň však řešení těchto etických aspektů nelze nechat pouze v rukou samotných tvůrců konkrétních technologií či nekritických technologických optimistů. Proto i v souvislosti s diskuzí etických aspektů analytiky učení považujme za nutné, aby zazněl hlas pedagogů a odborníků na vzdělávání. Doufáme, že tato studie bude př́nosná jako uvedení analytiky učení do širšího povědomí českých výzkumníků, ale také jako motivace k promýšlení mnoha metodologických i tematických otázek týkajících se daného tématu. Budeme rovněž rádi, pokud studie povzbudí autory $\mathrm{k}$ dalším publikacím, diskuzím a zejména výzkumům.

\section{Literatura}

Arnold, K. E., \& Pistilli, M. D. (2012). Course signals at Purdue: Using learning analytics to increase student success. In S. B. Shum, D. Gasevic, \& R. Fergusson (Eds.), Proceedings of the 2nd international conference on learning analytics and knowledge (s. 267-270). New York: ACM Press.

Baker, R. S., \& Inventado, P. S. (2014). Educational data mining and learning analytics. In J. A. Larusson \& B. White (Eds.), Learning analytics: From research to practice (s. 61-75). New York: Springer. 
Baker, R. S., \& Yacef, K. (2009). The state of educational data mining in 2009: A review and future visions. Journal of Educational Data Mining, 1(1), 3-17.

Bienkowski, M., Feng, M., \& Means, B. (2012). Enhancing teaching and learning through educational data mining and learning analytics: An issue brief. Dostupné z https://tech. ed.gov/wp-content/uploads/2014/03/edm-la-brief.pdf

Brooks, C., Greer, J., \& Gutwin, C. (2014). The data-assisted approach to building intelligent technology-enhanced learning environments. In J. A. Larusson \& B. White (Eds.), Learning analytics: From research to practice (s. 123-156). New York: Springer.

Campbell, J. P., \& Oblinger, D. G. (2007). Academic analytics. Dostupné z http://net.educause. edu/ir/library/pdf/PUB6101.pdf

Clow, D. (2013). An overview of learning analytics. Teaching in Higher Education, 18(6), 683-695.

Cooper, A. (2012a). What is analytics? Definitions and essential characteristics. JISC CETIS Analytics Series, 1(5), 1-10. Dostupné z http://publications.cetis.ac.uk/wp-content/ uploads/2012/11/What-is-Analytics-Vol1-No-5.pdf

Cooper, A. (2012b). A brief history of analytics. JISC CETIS Analytics Series, 1(9), 1-21. Dostupné z http://publications.cetis.ac.uk/wp-content/uploads/2012/12/Analytics-Brief-HistoryVol-1-No9.pdf

Dawson, S., Bakharia, A., \& Heathcote, E. (2010). SNAPP: Realising the affordances of real-time SNA within networked learning environments. In L. Dirckinck-Holmfeld, V. Hodgson, C. Jones, M. de Laat, D. McConnell, \& T. Ryberg (Eds.), Proceedings of the 7th international conference on networked learning (s. 125-133). Lancaster: Lancaster University.

de Laat, M., \& Schreurs, B. (2013). Visualizing informal professional development networks: Building a case for learning analytics in the workplace. American Behavioral Scientist, 57(10), 1421-1438.

De Liddo, A., Shum, S. B., Quinto, I., Bachler, M., \& Cannavacciuolo, L. (2011). Discourse-centric learning analytics. In P. Long (Ed.), Proceedings of the 1st international conference on learning analytics and knowledge (s. 23-33). New York: ACM Press.

Dringus, L. P. (2012). Learning analytics considered harmful. Journal of Asynchronous Learning Networks, 16(3), 87-100.

Dyckhoff, A. L., Zielke, D., Bültmann, M., Chatti, M. A., \& Schroeder, U. (2012). Design and implementation of a learning analytics toolkit for teachers. Educational Technology \& Society, 15(3), 58-76.

Ferguson, R. (2012a). Learning analytics: Drivers, developments and challenges. International Journal of Technology Enhanced Learning, 4(5-6), 304-317.

Ferguson, R. (2012b). The state of learning analytics in 2012: A review and future challenges. Technical report KMI-12-01. Dostupné z http://kmi.open.ac.uk/publications/techreport/ kmi-12-01

Ferguson, R., \& Shum, S. B. (2012). Social learning analytics: Five approaches. In S. B. Shum, D. Gasevic, \& R. Ferguson (Eds.), Proceedings of the 2nd international conference on learning analytics and knowledge (s. 23-33). New York: ACM Press.

Fritz, J. (2011). Classroom walls that talk: Using online course activity data of successful students to raise self-awareness of underperforming peers. The Internet and Higher Education, 14(2), 89-97.

Garciá-Saiz, D., \& Zorilla, M. (2011). E-learning web miner: A data mining application to help instructors involved in virtual courses. In M. Pechenizkiy, T. Calders, C. Conati, S., Ventura, C. 
Romero, \& J. Stamper (Eds.), Proceedings of the 4th international conference on educational data mining (s. 323-324). Eindhoven: Eindhoven University of Technology.

Gašević, D., Zouaq, A., \& Janzen, R. (2013). „Choose your classmates, your GPA is at stake!” The association of cross-class social ties and academic performance. American Behavioral Scientist, 57(10), 1460-1479.

Goldstein, P. J., \& Katz, R. N. (2005). Academic analytics: The uses of management information and technology in higher education. ECAR Research Study 8. Dostupné z http://net.educause. edu/ir/library/pdf/ers0508/rs/ers0508w.pdf

Govaerts, S., Verbert, K., Duval, E., \& Pardo, A. (2012). The student activity meter for awareness and self-reflection. In J. A. Konstan (Ed.), CHI'12 extended abstracts on human factors in computing systems (s. 869-884). New York: ACM Press.

Graf, S., Ives, C., Rahman, N., \& Ferri, A. (2011). AAT: A tool for accessing and analysing students' behaviour data in learning systems. In P. Long (Ed.), Proceedings of the 1st international conference on learning analytics and knowledge (s. 174-179). New York: ACM Press.

Greller, W., \& Drachsler, H. (2012). Translating learning into numbers: A generic framework for learning analytics. Educational Technology \& Society, 15(3), 42-57.

Hecking, T., Ziebarth, S., \& Hoppe, H. U. (2014). Analysis of dynamic resource access patterns in online courses. Journal of Learning Analytics, 1(3), 34-60.

Chatti, M. A., Dyckhoff, A. L., Schroeder, U., \& Thüs, H. (2012). A reference model for learning analytics. International Journal of Technology Enhanced Learning, 4(5-6), 318-331.

Johnson, L., Adams, S., \& Cummins, M. (2012). The NMC Horizon report: 2012 higher education edition. Dostupné z http://www.nmc.org/pdf/2012-horizon-report-HE.pdf

Johnson, L., Adams Becker, S., Cummins, M., Estrada, V., Freeman, A., \& Hall, C. (2016). NMC Horizon report: 2016 higher education edition. Dostupné z http://cdn.nmc.org/media/2016-nmchorizon-report-he-EN.pdf

Johnson, L., Adams Becker, S., Cummins, M., Estrada, V., Freeman, A., \& Ludgate, H. (2013). NMC Horizon report: 2013 higher education edition. Dostupné z http://www.nmc.org/pdf/2013horizon-report-HE.pdf

Johnson, L., Adams Becker, S., Estrada, V., \& Freeman, A. (2014). NMC Horizon report: 2014 higher education edition. Dostupné z http://www.nmc.org/pdf/2014-nmc-horizon-report-he-EN.pdf

Johnson, L., Adams Becker, S., Estrada, V., \& Freeman, A. (2015). NMC Horizon report: 2015 higher education edition. Dostupné z http://cdn.nmc.org/media/2015-nmc-horizon-report-HEEN.pdf

Johnson, L., Smith, R., Willis, H., Levine, A., \& Haywood, K. (2011). The 2011 Horizon report. Dostupné z http://www.nmc.org/pdf/2011-Horizon-Report.pdf

Juhaňák, L. (2013, záŕí). Analytika učení a dolování dat v oblasti e-learningu. Příspěvek prezentovaný na XXI. konferenci České asociace pedagogického výzkumu, Ústí nad Labem.

Juhaňák, L. (2014, ř́jen). Analytika učení - o čem mluvíme a co už víme. Příspěvek prezentovaný na konferenci AEDUCA, Olomouc.

Kaushik, A. (2011). Webová analytika 2.0: kompletní průvodce analýzami návštěvnosti. Brno: Computer Press.

Kim, M., \& Lee, E. (2012). A multidimensional analysis tool for visualizing online interactions. Educational Technology \& Society, 15(3), 89-102.

Kužílek, J., Hlosta, M., Herrmanová, D., Zdráhal, Z., Václavek, J., \& Wolff, A. (2015). OU Analyse: Analysing at-risk students at the Open University. Learning Analytics Review, no. LAK15-1. 
Dostupné z http://www.laceproject.eu/publications/analysing-at-risk-students-at-openuniversity.pdf

Lal, P. (2014). Designing online learning strategies through analytics. In F. J. García-Peñalvo \& A. M. Seoane-Pardo (Eds.), Online Tutor 2.0: Methodologies and case studies for successful learning (s. 1-15). Hershey: IGI Global.

Larusson, J. A., \& White, B. (2014). Learning analytics: From research to practice. New York: Springer.

Leony, D., Pardo, A., de la Fuente Valentín, L., de Castro, D. S., \& Kloos, C. D. (2012). GLASS: A learning analytics visualization tool. In S. B. Shum, D. Gasevic, \& R. Ferguson (Eds.), Proceedings of the 2nd international conference on learning analytics and knowledge (s. 162-163). New York: ACM press.

Long, P., \& Siemens, G. (2011). Penetrating the fog: Analytics in learning and education. Educause Review, 46(5), 31-40.

Macfadyen, L. P., \& Dawson, S. (2012). Numbers are not enough: Why e-learning analytics fail to inform an institutional strategic plan. Educational Technology and Society, 15(3), 149-163.

Mareš, J. (2015, září). Předpovídání úspěšnosti studentova výkonu v e-learningu: můžeme vytvořit systém včasného varování? Příspěvek prezentovaný na konferenci Information and communication technology in education, Rožnov pod Radhoštěm.

Nezvalová, D. (2003). Akční výzkum ve škole. Pedagogika, 53(3), 300-308.

Rabbany, R., Elatia, S., Takaffoli, M., \& Zaïane, O. R. (2014). Collaborative learning of students in online discussion forums: A social network analysis perspective. In A. Peña-Ayala (Ed.), Educational data mining: Applications and trends (s. 441-466). Cham: Springer.

Romero, C., \& Ventura, S. (2013). Data mining in education. Wiley Interdisciplinary Reviews: Data Mining and Knowledge Discovery, 3(1), 12-27.

Santos, J. L., Govaerts, S., Verbert, K., \& Duval, E. (2012). Goal-oriented visualizations of activity tracking: A case study with engineering students. In S. B. Shum, D. Gasevic, \& R. Ferguson (Eds.), Proceedings of the 2 nd international conference on learning analytics and knowledge (s. 143-152). New York: ACM Press.

Sclater, N. (2014). Code of practice for learning analytics: A literature review of the ethical and legal issues. Jisc. Dostupné z http://repository.jisc.ac.uk/5661/1/Learning_Analytics_A-_ Literature_Review.pdf

Schreurs, B., \& De Laat, M. (2012). Network awareness tool - learning analytics in the workplace: Detecting and analyzing informal workplace learning. In S. B. Shum, D. Gasevic, \& R. Ferguson (Eds.), Proceedings of the 2nd international conference on learning analytics and knowledge (s. 59-64). New York: ACM Press.

Shum, S. B. (2012). Learning analytics. Policy brief. Dostupné z http://iite.unesco.org/pics/ publications/en/files/3214711.pdf

Shum, S. B., \& Ferguson, R. (2012). Social learning analytics. Educational Technology \& Society, 15(3), 3-26.

Siemens, G. (2010). What are learning analytics? Dostupné z http://www.elearnspace.org/ blog/2010/08/25/what-are-learning-analytics/

Siemens, G. (2012). Learning analytics: Envisioning a research discipline and a domain of practice. In S. B. Shum, D. Gasevic, \& R. Ferguson (Eds.), Proceedings of the 2nd international conference on learning analytics and knowledge (s. 4-8). New York: ACM Press. 
Siemens, G. (2013). Learning analytics: The emergence of a discipline. American Behavioral Scientist, 57(10), 1380-1400.

Slade, S., \& Prinsloo, P. (2013). Learning analytics ethical issues and dilemmas. American Behavioral Scientist, 57(10), 1510-1529.

Van Barneveld, A., Arnold, K., \& Campbell, J. (2012). Analytics in higher education: Establishing a common language. Dostupné z http://www.educause.edu/library/resources/analyticshigher-education-establishing-common-language

Zounek, J. (2009). E-learning - jedna z podob učení v moderní společnosti. Brno: Masarykova univerzita.

Zounek, J., Juhaňák, L., Staudková, H., \& Poláček, J. (2016). E-learning. Učení (se) s digitálními technologiemi. Praha: Wolters Kluwer ČR, a. s.

\section{Autoři}

Mgr. Libor Juhaňák, Masarykova univerzita, Filozofická fakulta, Ústav pedagogických věd, Arna Nováka 1, 60200 Brno, e-mail: juhanak@phil.muni.cz

doc. Mgr. Jiří Zounek, Ph.D., Masarykova univerzita, Filozofická fakulta, Ústav pedagogických věd, Arna Nováka 1, 60200 Brno, e-mail: zounek@phil.muni.cz

\section{Learning analytics: A new approach to the study of learning (not only) in virtual environments}

Abstract: The aim of this study is to present and describe an emerging research area known as learning analytics. This research area focuses on the use of quantitative methods in research on learning and teaching especially in virtual environments. In the first part of the paper we discuss the historical roots of analytics in education and we identify various sources of its inspiration. Also, we put learning analytics into context with related research areas in the field of technology enhanced learning. The second part of the study focuses on the definition of learning analytics and clarification of concepts and terms. At the same time, the paper describes and compares some of the main concepts used in the field (macro, meso and micro-levels of analytics in education, learning analytics process). The third part of the study presents the main research directions within the field of learning analytics that were identified in the relevant existing literature.

Keywords: learning analytics, e-learning, virtual learning environment, methodology 